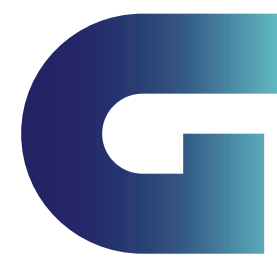

The Program on Governance and Local Development at Gothenburg
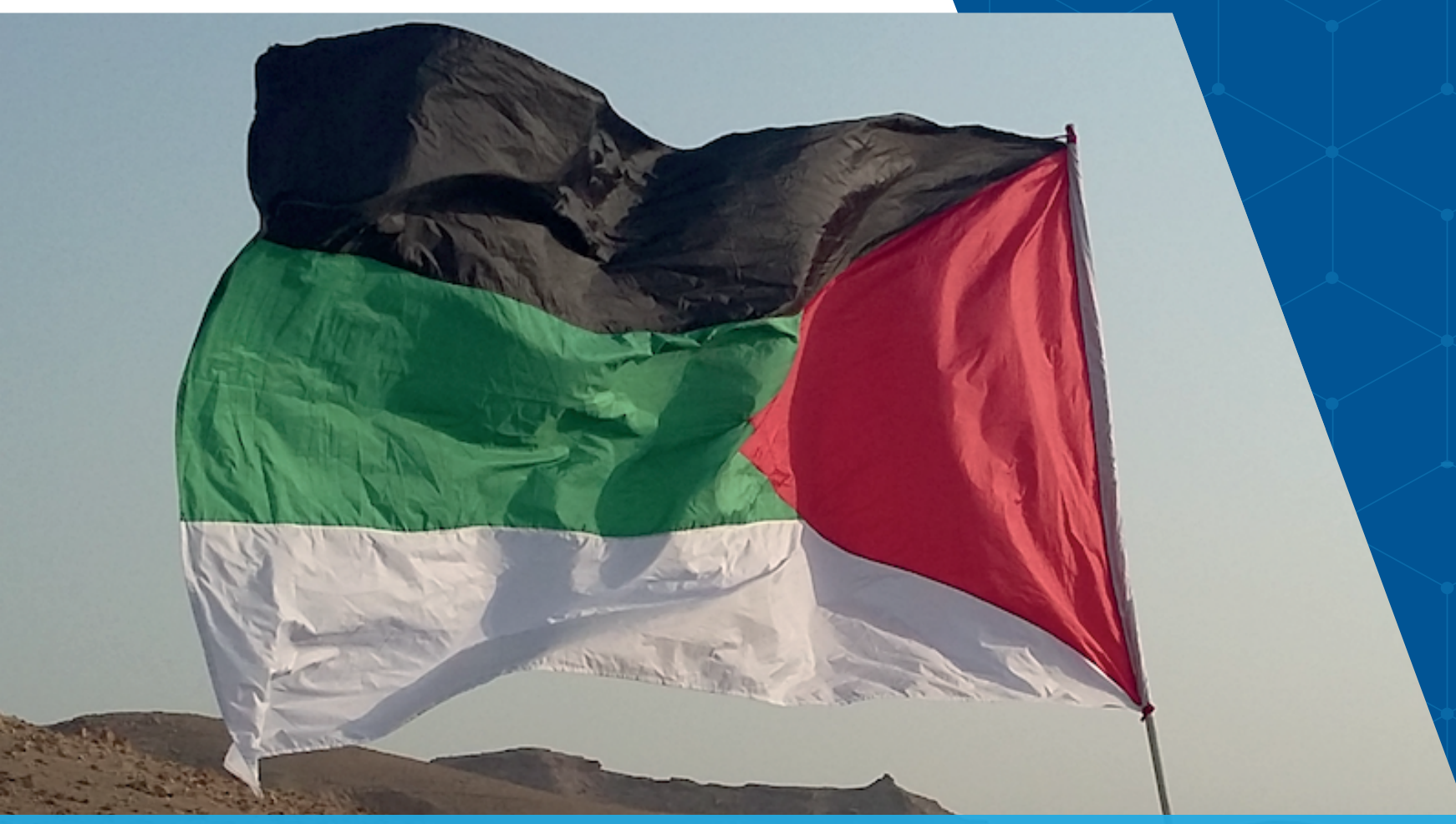

Tribes without Sheikhs?

Technological Change, Media Liberalization, and Authority in Networked Jordan

\title{
Geoffrey Hughes
}

\section{Working Paper}

No. 242019 
Front Cover Image: The flag of the "Great Arab Revolt" (Source: author's own) 
Tribes without Sheikhs?

Technological Change, Media Liberalization, and Authority in Networked Jordan

\author{
Geoffrey Fitzgibbon Hughes \\ University of Exeter \\ G.Hughes3@exeter.ac.uk
}




\section{Acknowledgements}

This research was funded by the National Endowment for the Humanities. I would especially like to thank Barbara Porter and the staff at the American Center of Oriental Research in Amman for hosting me, as well as the countless Jordanians who welcomed me but must remain anonymous. I would also like to thank Kristen Kao, Ellen Lust, and the attendees of Gothenburg University's 2018 Governance and Local Development Conference for their help in improving this paper. Any views and opinions expressed are not theirs, and any errors are, of course, my own responsibility. 


\begin{abstract}
This paper examines the ways in which Jordan's rapidly evolving media sector is transforming the nature of authority in Jordan. An older generation of leaders, known as sheikhs, confronts technologies they often don't understand and a new generation that has little respect for its elders' ancestral claims. Amid a proliferation of social media tools that allow young people to use the idiom of the tribe to act quickly and decisively — even violently —in the political field without regard for their elders, the Jordanian government seeks to reassert control over a media sector that is increasingly international, for profit, and privately held. Yet a new generation of would-be tribal leaders is rushing into the breach. Drawing on case studies of sheikhs, police officers, and journalists, this paper argues that the future of authority in Jordan will depend on the continued ability of leaders to use media to move between various scales of socio-political organization, representing themselves individually while also convincingly standing in for lineages of various sizes and, indeed, the nation itself.
\end{abstract}




\section{Introduction}

While the state (polis) is the locus classicus of politics, recent decades have seen an increasing focus on the role of the media in politics in both scholarship (Calhoun 1992, Habermas 1989, Warner 2002) and the popular imagination. Jordan, where I have been conducting ethnographic research for the past decade, is no exception to this trend. In tandem with technological changes and new regulatory paradigms, the media (al-ilam) has become a topic of intense speculation among people of all ages and walks of life, from members of a new generation of iconoclastic online journalists to grizzled old rural notables known as sheikhs. In this paper, I seek to probe the significance of this increasingly nebulous and allencompassing concept of media in its many entanglements with technological change. At a time when companies such as Facebook are working hard to convince governments that they are "a technology company" and "not a media company" (Castillo 2018), the distinction seems less and less salient. Indeed, the ability of these new forms of media to obfuscate that very distinction seems key to their skill in circumventing regulation. As a result, I do not offer a coherent theory of media as such. Rather, I trace out a local, Jordanian set of beliefs about media ethnographically and offer some observations about their political implications. I argue that this convergence of scholarly and lay explanatory frameworks around the figure of "media" reflects_-but also advances—a marked renegotiation of the state-society divide (Mitchell 1991) that is transforming local conceptions of authority.

As governments across the globe relinquish some of their control over newspapers, radio, and television at the same time that the Internet is emerging as a new, more-difficult-to-regulate alternative to these older forms of media, "the media" itself seems more and more like a center of power in its own right. Authority consequently seems both more diffuse and more allencompassing, increasingly identified with the work of mediation itself. Drawing on the Jordanian case, I demonstrate in this article that the changes are both global and local in nature, combining broader shifts in technology and elite governance paradigms with deep local histories of contestation and accommodation involving global powers, local government institutions, and their citizenries. At least in Jordan, far from being a purely disruptive phenomenon, the emerging accommodation between old authority structures and new media is breathing new life into tribal modes of social organization, whose decline has been predicted 
for well over a century. ${ }^{1}$ The resulting dynamic offers new ways to act on behalf of lineages of various sizes and, indeed, the nation itself-but without necessarily needing either sheikhs or formal state backing.

Certain social and technical aspects of these transformations will no doubt be familiar to people working around the world. If the twentieth century saw what Russian-history expert Peter Kenez has called "the birth of the propaganda state" (1985), then the twenty-first century sees that propaganda state in full retreat. It is easy to forget that there was a time when even proponents of liberal democracy saw state propaganda (Lipmann 1922), or at least statebacked progressive education (Dewey 1927), not as an impediment to the liberal state but indeed as one of its most important tools. Yet times have changed—and not just in the heartlands of liberal democracy. Even self-styled authoritarian regimes, such those in Russia (Price et al. 2002, Sparks 2008, Skillen 2016) and China (Brady 2008 and 2012, He 2000, Lynch 1999, Zhao 1998, Zhu 2012), have largely outsourced their media operations since the 1980s. This trend is reflected in countries like Jordan, as well.

As in many other parts of the world, in the Middle East the sixties and seventies served as a high-water mark for state-run media, while the eighties and nineties saw a brief efflorescence of a quasi-independent—although some would call it yellow or tabloid—press (Armbrust 1996, Lynch 1999). Then came the 2000s: the era of Al-Jazeera and transnational satellite TV (Lynch 2005, Miles 2005). This paper picks up the story in the 2010s, to explore the ways in which the sudden ubiquity of the Internet, social media, and smart phones affects shifting constructions of authority in contemporary Jordan. Freedom House estimates Internet penetration in Jordan to be 62 percent (Freedom House 2017). According to a 2016 survey by the research firm IpsosJo reported on in the Jordan Times, 93 percent of Jordanian Internet users use social media of some kind, 91 percent use Whatsapp, and 80 percent use Facebook. With 85 percent of those Facebook users checking Facebook every day (Jordan Times 2018), Facebook represents one of the main ways that Jordanian Internet users experience the Internet and, as such, the wider world. While the Jordanian government has been eager to style itself as a player in the knowledge economy, it can hardly take credit for this mini social-media

\footnotetext{
${ }^{1}$ Among others, Claude Conder (1882:356, quoted in Layne 1994:14) predicted the "wilder" tribes would "finally disappear" and give way to other, "energetic and civilized races."
} 
tech boom. Instead, though the state marks out the boundaries of acceptable public discourse, decentralization and marketization mean that media organizations-many of them privately held, profit-seeking endeavors-are allowed and even encouraged to demonstrate independent initiative.

In Jordan and the Middle East, regional considerations have also shaped trends in technology and elite political sensibilities. These considerations included fears of Islamic radicalism (Gaffney 1998:124-165, Hirschkind 2006:105-142, Starrett 1995:191-219), the discrediting of Arab nationalism (Armbrust 1996:165-220), and the complexities of explaining Arab states' perennially compromised relationships with world powers to impatient and often fearful citizenries (Lynch 1999, 2005). The result has been the partial acceptance of a wider space for nominally private-sector discourse, but with firm state oversight, lest things get out of hand. One aspect of changing media dynamics that is somewhat peculiar to Jordan is the longrunning attempt of leading state-aligned intellectuals to promote the notion that Jordan is a confederation of tribes arranged along the lines of kinship and heredity, with the king and his ruling Hashemite house serving as paramount sheikhs. Throughout the past half-century, this tribal conception of Jordan has served as an ideological bulwark, first against communism and Arab nationalism and later against Palestinian nationalism and Islamism (Layne 1989, Massad 2001:100-162, Shryock 1996 and 2000). Thus, it is little wonder that Jordan's media landscape must accommodate the realities of this manner of conceptualizing and enacting legitimate authority, known locally as tribalism ('asha'iriyya).

I have written elsewhere (Hughes 2018) about a widespread genre of media talk in Jordan that is elegiac and highly critical of changing media-consumption patterns. Within this discourse, the uptake of social media in Jordan—particularly in rural areas-becomes strongly associated with an uptick in tribal feuding, because new communication platforms are believed to offer young people avenues for circumventing preexisting authority structures. Traditional tribal authority structures in Jordan are explicitly and unapologetically gerontocratic, making generational conflict inherent to their functioning. Yet older men in particular see new, more decentralized modes of communication as undermining state authority (not to mention their own) and threatening to send Jordan spiraling into the abyss by shifting the balance of power toward the young. In doing so, they are developing what the linguistic anthropologist Ilana 
Gershon has termed a "media ideology": "beliefs, attitudes, and strategies" about particular modes of communication (2010:389). Focusing on media ideologies is a methodological move that allows me to integrate myself into social networks by participating in prominent, ongoing conversations, moving from node to node as those trying to help me with my research direct me to those they consider to be the sources of this discourse. At the same time, by framing my object of study as an ideology, I maintain an open-mindedness about its underlying claims: while such media ideologies could not persist if they were too clearly incorrect, I am also keen to keep an eye out for evidence of cognitive dissonance, both in others and in myself.

This paper is based on approximately six months of dedicated ethnographic fieldwork. Drawing on an extensive knowledge of Jordan gleaned from three and a half years previously spent living, working, and researching there, I eventually interviewed 20 journalists, nine intellectuals, six lawyers, 14 tribal leaders, and five members of the security apparatus. I did this using a mix of snowball sampling (asking people I already knew to introduce me to others) and cold-calling, particularly with journalistic organizations: I got senior members of most major Jordanian news sources to sit down for formal, off-the-record interviews. When I wasn't chasing interviews, I spent countless hours in the capital city's cafes, newsrooms, and other spaces where people gathered to talk to (and more importantly listen to) those involved in media work. Much of what I heard was scandalous and slanderous, often straining credulity. As the anthropologist Paul Dresch has noted, when conducting ethnographic research in the Middle East, "the more thriller-like the material, the less difficult to gather ... the more mundane and empirical the published facts, by contrast, the more collecting them resembled clandestine intrigue" (2000:109-110). While such an admission might undermine my own ethnographic authority, I take it to be a key part of the social field I seek to understand. As Dresch argues, "what empiricist anthropology sees as obstacles are social facts" (2000:112). Namely, the normative conceptions of publicity and privacy that ethnography inevitably lays bare also tell us a lot about how these concepts structure broader patterns of sociality.

I present my findings here through case studies: abstractions from my dealings with some of my closer interlocutors designed to highlight and accentuate commonalities among the wider sample, as well as prevailing social dynamics more generally. This allows me to respect people's privacy while highlighting tensions and contradictions in popular narratives and interpersonal 
engagements without putting individuals on the spot. Indeed, my own positionality as someone who takes U.S. government funding to study how people creatively appropriate and resist new globalized modes of control is certainly the most fraught of all: no wonder people sometimes treated me like a spy. This dynamic was widely noted by my interlocutors and further accentuated some of the dynamics that pervaded my sample of interviews and even my casual interactions with Jordanians interested in what I was doing: mistrust, paranoia, alienation, and a pronounced fear that someone else was able to manipulate tools that were becoming ever more intimately involved in one's life. Perhaps the only exceptions to this were the young and the especially marginalized, who often took pleasure in the consternation that new media seemed to generate among the powerful—even if they rarely reported feelings of sustained empowerment.

I offer three profiles — the sheikh, the police officer, and the journalist, all of whom ironically saw new media as bolstering the authority of the others at their own expense. ${ }^{3}$ While the sheikh and the police officer saw new media as a threat to the status quo and threatening to rend the social fabric, the journalist painted a picture of an effectively decentralized, outsourced, selffunding form of propaganda. I argue that each in his own way betrayed a paralyzing paranoia and cynicism that maintained a tenuous tribal status quo with surprising efficiency. Somewhat counterintuitively, as a media ideology proliferated that posited a hidden world of shadowy intrigue behind the phenomenal world of everyday life, there was a simultaneous retreat into an essentialist fixation on so-called blood ties of tribalism. In the final section of the paper, I show how the tensions that these dynamics create flared up in the most noteworthy controversy that coincided with my research: large-scale protests by a soldier's kinsmen following his conviction for the murder of four United States military trainers. I argue that this course of events validated aspects of all three accounts, while ultimately failing to validate everyone's worst fears. Events were indeed chaotic at times, but there were also limits to both the chaos and the degree to which the authorities could hope to contain that chaos. In the conclusion, I suggest that the insights of my Jordanian interlocutors might be applicable to Western liberal democracies, which also show evidence of a growing culture of suspicion and paranoia regarding the media.

\footnotetext{
${ }^{3}$ The inability to find people who report feeling consistently empowered by social media-even among those widely reputed to be so empowered-has been noted by others, such as Gershon in her 2010 study of elite university students, The Breakup 2.0.
} 


\section{The Sheikh}

The sheikh is a diminutive older man with a keen mind. He is enjoying a comfortable retirement from his role as an influential member of the security services, surrounded by his sons, whose beautiful, new houses encircle his much older home. They are relatively well off, but not necessarily the richest in the area. I first met him because his kinsmen were eager to introduce us. They fretted that I would get the wrong idea about the area if I spoke only with other local notables (who would inevitably downplay his importance and portray his behavior in local power struggles in a comparably negative light). I was happy to oblige them. Whenever I am in the area now, I make a point of calling on him, a demonstration of respect and an opportunity to learn from him and be honored by his hospitality. As a local notable, he is exceedingly diplomatic in his communication, always clear in his support for the pillars of the status quo that undergird his own claims to authority in the community ("God, King, and Country"). For a man who doesn't have a Facebook account and uses a Nokia phone whose most distinctive selling point is its flashlight, the sheikh has a lot to say about social media. As he often complains of his younger kinsmen, "They bring me phones from far away! ... Us in the old times, we didn't have phones in our customs." He frets that his suggestion to throw away the phones is always ignored; he senses that he and others of his generation are losing a battle with the phones for the respect and obedience of the youth. "It used to be the people would listen to the elderly. Now no one listens to the old." Bemoaning the decline of the prerogative of the eldest brother to regulate the violence of his younger brothers' descendants, he continues, “The fights are getting stronger, and with some of them the uncle can't keep [his own kinsmen] out of the fight." For this sheikh and most like him, it is inconceivable that tribes could survive without the gerontocratic power structures whose heights they command.

The sheikh is also a tribal judge. This means that he has long enjoyed government recognition of his role in solving conflicts that the authorities deem to be inextricably linked to tribal customs and traditions. This makes the sheikh a wasta in both of the senses developed by Robert Cunningham and Yasin Sarayrah in Wasta: The Hidden Force in Middle Eastern Society: "mediator" and "intercessor." While the sheikh retains features of the sheikhly role of mediator associated with social logics predating the Jordanian state, he is also very much an intercessor with that state (1993:8-9). The sheikh reckons he has seen 1,000 cases in his life- 
at least 60 per year. ${ }^{4}$ These include the government-recognized crimes of "blood" (homicide), "honor" (sexual crimes), and "cutting the face" (the breaking of truces). In practice, a much wider range of disputes comes under his ambit than the three acknowledged by the government. "Lots of people decide not to go to the courts at all," he explains. "They just bring it to the tribal judge and he solves it right there. [For instance] there's a [civil] law against slander here and in Britain, but a tribal judge will solve it, too." Car accidents are a source of endless controversy that keep him busy and his mediation skills sharp. But, he says, "It's mostly fights."

The most serious cases of blood, honor, and cutting the face involve a carefully choreographed progression in which the sheikh works hand-in-hand with the state, conforming to-but also transforming - the stateless modes of authority that had been at the heart of tribal dispute resolution prior to its reorganization under British rule. Banishment (jalwa), once forced upon the perpetrator and his kin by the enraged defenders of the victim under threat of violence, has come to involve the perpetrator and those listed in his government-issued "family notebook" facing banishment at the hands of the governor-ostensibly for reasons of public order. The "truce of the boiling blood," (an initial cooling off period negotiated amongst the antagonists which lasted three and a third days), has become a security truce imposed by the governor for the same duration. The respective sides continue to select their own judges and guarantors (who promise to pay a large surety should their kinsmen break the truce), but now their prerogatives have come to be backed by the state, which will step in to assist in cases of "cutting the face." Through a series of longer, less exacting truces, judges still try to engineer a state of forgiveness, mercy, and, ultimately, reconciliation among the antagonists, through a blood money payment and the ritual pageantry of the meetings themselves. Yet ideologically, at least, the state now holds that this aspect of the case, which is for the victim (dahiyya), can lead only to a sentence reduction. According to the sheikh, "a homicide is 15 years [in prison], but the state will cut it in half if there is reconciliation [between the families]: seven and a half years for the victim and seven and a half for the state."

\footnotetext{
${ }^{4}$ Sixty cases per year would be more than one per week. While one might see this as embellishment, I think it more likely represents the sheikh's primary mode of engagement with the world around him as a series of conflicts to be mediated.
} 
Even if state prerogatives prove impossible to exercise in many cases, the concept of state authority has inarguably come to suffuse most facets of a previously stateless system of dispute mediation. Indeed, at the time of research, it was clear that many conflicts that could be resolved by the courts never make it to court; that victims' families in many cases continued to try to raze the homes of perpetrators' families; and that there was a pronounced fear that the well-connected could get away with murder. To the degree that social media promotes these challenges to the state-backed status quo, they provide a raison d'être for men like the sheikh. Yet social media also leaves sheikhs in the unenviable position of bearing the same responsibility for the actions of their kin while offering those kinsmen new avenues for selforganization. "All the young men are on their phones," says the sheikh. "Even in gatherings. Even the men around us aren't [listening to] us. The role of the sheikh is gone. Now there are people making Facebook pages for sheikhs. How can a Facebook page take the place of a sheikh?”

It is not just technology, though, but how it interacts with broader trends and state policies. Speaking of the Arab Spring, the sheikh grows circumspect and chooses his words carefully. "There's a political interpretation." Mixing speculation with the recollection of widely circulated images of the first protests for reform in Jordan in 2011, when the police initially welcomed protest in a highly performative fashion before later cracking down, he eyes me before continuing. "The Jordanian regime was dealing with a lot of protests and giving them room to blow off steam, and [the police were] giving [the protesters] water and juice." ${ }^{\prime 5} \mathrm{He}$ complains, however, that the failure to use a "strong hand" allowed things to spiral out of control, as young people saw what they could get away with and incited one another to greater violence. "Now there's a weakening of the security situation, and they've started committing crimes with theft and stealing cars and everything. It's an indirect effect of the Arab Spring weakening the security situation." As he moves rapidly among the state, media, and talk of young delinquents, it is hard to ascertain who, exactly, the "they" in his comment are and how these actors are related. I sensed he was not in the mood to be interrogated. Backing away from potentially hazardous terrain to the safer ground of complaining about a much-alleged-

${ }^{5}$ The distribution of water and juice to protesters was widely covered in the Western media (Baker 2011; Amos 2013). 
though hard to verify ${ }^{6}$ - post-Arab Spring crime wave, he said, "Tribalism is what protects the security of the country... The tribes listen to one another more than they listen to the state... The central family is the Hashemite family, and god forbid that anything change that."

\section{The Policeman}

While perhaps 20 years the sheikh's junior, a college graduate, and much more comfortable with technology, the policeman shares the sheikh's dim view of recent developments and his pessimistic prognosis for Jordan's future. ${ }^{7}$ Like the sheikh, he sees the confluence of new media, a breakdown of patriarchal authority, and dissident politics as a perfect storm of selfreinforcing dynamics that threaten to send Jordan careening into chaos. His work focusing on youth crime puts these issues front and center in his mind, and he seeks to balance a nostalgic appreciation for the old ways of doing things with a commitment to professionalism that involves keeping up with the latest best practices in progressive policing methodologies. As with the sheikh, the policeman and I spoke with an appreciation for the need for circumspection; I often had to avoid pushing too hard on a particular line of questioning so as to not put him in an awkward position.

The policeman would often say that there needs to be either one source of media, controlled by the state, or a powerful press syndicate that would allow only reputable journalists using reputable sources. To the degree that such structures have weakened in recent decades, the policeman sees members of the security services, such as himself, bearing much of the brunt. "We're still not very developed in the regulation of this new media, unlike you in the West, perhaps. So we only have negative effects," he says. "There needs to be kontrül," he adds, striking the table with his hand and code-switching into English. In his estimation, news sites are motivated solely by their need for attention, followers, and views - to the detriment of social order. Using a recent example from his own village, he explains the negative impact of

\footnotetext{
${ }^{6}$ While police officers were adamant that crime was on the rise, the people at the courthouse with access to the data were equally adamant that the increase was in line with population growth and overblown. Journalists sometimes wondered whether their coverage encouraged crime but also tended to defend themselves by saying that "the difference is that now we hear about it."

7 The age differential between the sheikh and the policeman is inherent in their roles: before retiring and taking on his current role, the sheikh worked in the security apparatus. The policeman might well be a notable-even a sheikh-20 years hence, depending on how many elder brothers he has and the vagaries of life. This is a typical career progression; sensibilities about the state and tradition tend to be enculturated among such men through a life trajectory that includes time in the security apparatus, as well as a retirement spent in a more supporting role. As the state-society divide is renegotiated, though, a new generation of leaders with a more arms-length relation to these state authority structures could prove to operate in a qualitatively different manner.
} 
social media to me with forensic precision. The problems started with a dispute over a parking space but escalated after blows were exchanged. Youths on both sides used tools like Whatsapp and Facebook to coordinate subsequent violence. "Every tribe has its own Facebook group. They say, 'Let's meet here at this time and take revenge.' This is because when someone kills a member of one tribe, members of that tribe believe they must kill a member of the other tribe to make it even. They do not wait for an investigation, and they do not care whether the person who dies is the killer."

What's more, he believes the existence of new media normalizes the violence, sowing fear and encouraging young men to behave more aggressively than they would otherwise. "They do not go into the fight wanting to kill. They want to look strong and become sheikhs, so they take pictures of themselves with guns and knives and put them on the Internet." This highlights a way in which media might become a means of realizing new, violent forms of selfexpression and self-actualization.

Even worse, he charges that the media exaggerates the scope of the problem. "If you read the articles and saw the pictures these sites were publishing, you would think the situation was like Raqqa [Syria] or Mosul [Iraq]. But I was there myself? They just take a small corner of the situation. This adds to people's fear, which is another negative. There were people who were afraid to go home because of these reports." Here, media reports might lead to anxiety and even panic, creating a host of other policing challenges that must also be confronted. The allure and fear of violence might not be new, but, in his mind, the degree to which the media allows for the wider circulation of such images and behaviors represents a qualitative change in the sort of challenge he is confronting.

The policeman does not fault the tribes themselves for these sorts of problems. To the contrary, he sees tribes as a solution and argues that they prefigure the principles of community policing that he learned in some of his classes. In particular, he compares the system of tribal law extant in Jordan to the idea of the community-policing "social ladder," a term from criminology that was an important part of his curriculum. Community policing attempts to break down the state-society divide and make members of the community extensions of the security apparatus. For instance, when police are unable to achieve desired results on their 
own, bar owners, landlords, and/or universities may be encouraged or required to put pressure on law-breakers. ${ }^{8}$ Likewise, the policeman explains the ways in which tribal notables have long been used to control recalcitrant troublemakers. Still, he mocks some aspects of this model, saying that they are unrealistic. "People expect the security apparatus to do everything," he observes, "but we are just one part of the state. There are more basic problems of poverty and unemployment that we cannot affect. And then they want us to go out into the street and hug people. People don't want to hug us! They say, 'You take my money, arrest me, write me tickets, fine me, and put me in prison, and you want to hug me?!”

The policeman likens these new principles to the policing model of the 1970s and 1980s, arguing that the indigenous Jordanian policing philosophy of that era was a much more effective version of the community policing he is now being encouraged to practice. Speaking of his work in the juvenile crime division, he explains that the king encourages the police to treat young criminals as victims, instead of yelling at them, beating them, and throwing them in jail as if they were adults. The goal, the policeman underscores, is to identify the social causes of crime-poverty, unemployment, family problems, drug use-before they become too serious. He says that the first thing he does when a youth in his district is apprehended is to call the relevant sheikh, in an attempt to release the offender to him in a guarantor capacity. "It's not effective to go out and hug the youth who is smoking in the street," he says, "because he has no incentive to cooperate. But the shiekhs and 'faces' [leaders] are another matter. They have an interest in order. In fact, they are usually themselves retired from the security apparatus. So you serve 20 years in the police or the army and then you become a sheikh. If there is a problem, the police go to their former colleagues." He argues that both his trainers and those who had devised Jordan's older policing strategies understand the value of making more established community members responsible for more combustible elements of the population—but that really the tribes are key. While the policeman believes that the confluence of patriarchal authority, strong centralized control over the media, and political conformity all contribute to Jordan being a rare island of stability in a troubled region, he fears that this arrangement could easily unravel.

${ }^{8}$ Kristian Williams (2011) explores the frequent back-and-forth between community policing paradigms in the United States and counterinsurgency abroad. 


\section{The Journalist}

Like the sheikh and the policeman, the journalist also takes a dim view of the effect of new forms of media. The difference is that, where the others see the media gaining power at their expense, the journalist (like most journalists I spoke with) is hardly convinced that he is the beneficiary. The son of a mid-level officer in the General Intelligence Directorate (more commonly known as the mukhabarat), the journalist grew up in a tribal neighborhood in the capital, part of an earlier wave of urbanization that brought large number of tribesmen employed by the state from rural areas into Amman. Like his father, he is an ardent nationalist with a keen sense of disgust for the rampant corruption he sees around him. As is typical of those with an established place in the industry (and especially in front of an American interloper such as myself), he doesn't seem to fit into the neat pro-regime/opposition binary. While he is doing well personally, he is deeply aware of the increasing polarization of Jordanian society and is keen to underline that he can see what is happening around him. As he sees it, at one end of the socioeconomic spectrum is the more conservative and devout mass of hardworking, yet often underemployed citizens in neighborhoods like his. At the other end of the spectrum is a small elite that mimics western mores and allies itself with United States foreign policy while benefiting massively from privatization policies. The majority of our conversations centered on the intrigues that he attributes to Jordan's colonial and postcolonial sponsors-and the ways in which he believed our encounters were implicated in them. In a sense, we had both come to believe that we could learn about emerging regimes of publicity and secrecy from each other: modes of disclosure and systems of obfuscation.

The journalist, like most of his colleagues, would often counsel me not to be deceived by the people I was meeting. Even those who worked in the online media sector believed it to be a bit seedy: filled with propaganda, incitement, and the politics of personal destruction. Most of those in media, I was repeatedly told, were working for some intelligence agency or other. Stories were typically dissected with an eye to what U.S., Israeli, Iranian, or Jordanian state interests might be advanced by them. This was actually quite understandable and hardly novel. As in most places, a large percentage of the information that Jordanian journalists relied upon came directly from the security services. "Public Security publishes the correct information as a matter of the right of the citizen to information," explains the journalist matter-of-factly. "Of course, if I find extra information, I can publish it—as long as I provide documentation." 
At times, he blames himself and his colleagues for the poor professional standards of Jordanian journalism, arguing that, "Most journalists have no professionalism here. They just want it to be easy. They steal videos, pictures, text, and put their own name and logo on it. Then we have to call them and fight about it.... Of course, it is also safer to just say what Public Security says, but we can report what we want as well, so long as it isn't about the king or the queen."

In a darker mood, however, the same dynamics take on a more sinister cast. The journalist's boss had been imprisoned for promoting a video that embarrassed an important foreign dignitary, and one of his journalistic idols, Nahed Hattar, was shot dead by a preacher on the courthouse steps at his trial for sharing an allegedly blasphemous political cartoon on his Facebook page. ${ }^{9}$ In a moment of particularly acute cynicism, the journalist told me that someone who worked for the Intelligence Directorate once bragged to him that "the mukhabarat no longer need to bother monitoring demonstrations and documenting the participants for later surveillance." Now, the journalist notes wryly, they just "sit in the airconditioning" and let journalists like him do the documenting. These are but a handful of examples of the sorts of stimuli that had pushed him (and many of his colleagues) to cultivate a healthy mistrust of surface appearances.

Like most people I spoke with, the journalist had as many questions for me as I did for him. I had been hearing many of them since before the emergence of social media. What was to be made of the contradiction between the ubiquitous United States rhetoric of democracy promotion and the material reality of autocracy in the region? What of the on-again, off-again alliances of the United States and its Arab allies with everyone from Saddam Hussein to Osama bin Laden and the Muslim Brotherhood? It is hard to keep the allegiances straight, because everyone seems so cynical. Yet the frequency of unsuccessful, highly damaging military adventures on the part of Jordan, the United States, and their allies makes it difficult to attribute clear and coherent interests: could the United States really have been so stupid as to invade Iraq in an attempt to counteract terrorism? Clearly, the paranoia and the imputation of sinister motives to others is not new and does not require either social media or the privatization of formerly state-owned media.

\footnotetext{
${ }^{9}$ For a press account of the controversy and subsequent murder, see Bulos (2016).
} 
So when the Muslim Brotherhood did well in local elections, it was no wonder that the journalist saw a hidden hand. At the local level, he was disappointed that his own "tribal" candidate had lost out to the Muslim Brotherhood candidate, who had been backed heavily by those living in the neighboring Palestinian refugee camp. Claiming to have seen the votebuying himself in the barber shop ("The mukhabarat of the neighborhood.... You tell everything to the one who touches your head"), he explains, "They went into the camps and bought votes for 20 dinars each. These are really poor people. You have a family with nine or ten people.... That's like 180 or 200 dinars! That's like a month's salary for them.... I tell you, the day after the elections you could smell the cooking meat wafting from the refugee camp." The journalist assumed that this must have been orchestrated at higher levels and that it was his job to puzzle it out. Speaking of the Muslim Brotherhood's success at the national level, most notably in Zarqa, Jordan's second largest city, he reasons, "The state must be behind this." Considering how the figure of the state remains potent within contemporary media ideologies despite its ostensibly diminished role, he continues, "They allow the Muslim Brotherhood to exist. Without the state there would be no Muslim Brotherhood, so they must have a reason for supporting them." Growing more cynical, he suggests, "There are some nightclubs, bars, and liquor stores that need to be approved by the municipality. We will see if the Brotherhood approves them." Unlike others I have profiled—and even his own fatherwho have experience of working for the state, what is striking here is how the journalist sees the state as purely exterior or other.

Certainly Palestinian and Islamist journalists could-indeed did-make similar claims if and when the shoe was on the other foot, and my profiling of a Jordanian (or a Palestinian or an Islamist or a tribesman) could easily mask heterogeneity of the profession. I must also emphasize that these sorts of scenarios were often delivered in more informal moments with a mix of deadpan and sardonic detachment-but there is also always truth in jest. The journalists who liked to weave these scenarios for me and others were, of course, deeply aware of the stereotype that Arabs have a penchant for conspiracy theories but often gently mocked me as an American for being so credulous about surface appearances-while also distancing themselves from particular popular theories that they knew I would be familiar with but that they personally found implausible. Indeed, I was always keen to underline my acceptance of the fact that many of the most pivotal events in modern Middle Eastern history have been 
conspiracies designed to manipulate preexisting social cleavages for the benefit of outsiders: from Sykes-Picot and the partitioning of the region between the British and French to the invented rationale for the second Iraq war. What I want to emphasize is the media ideologies involved and how they hinged on shared notions of publicity and secrecy within a broader shared political context.

The same modes of reasoning about media through notions of state, publicity, and secrecy also manifested in explanations for the Jordanian government's indulgence of tribal custom and press coverage of so-called "tribal clashes." For all of the self-identified Palestinian and Islamist journalists I spoke to, coverage of these clashes minimized serious crimes and spoke to the different rules in effect for different communities in Jordan. When clashes exploded on college campuses, these commentators saw it as a massive indictment of the rule of law and a subjugation of the meritocratic premise of education to government quotas for its tribal supporters and those entitled to royal sponsorship at university because of their parents' employment in the security apparatus. ${ }^{10}$ Here, the media was merely making plain a dirty local secret. Yet for the tribally aligned journalist, the terminology was a malicious media attack on the rights of some of Jordan's most patriotic citizens to an education. What was striking was how something like a riot on a college campus could be explained as a sinister attempt to by the United States or the security apparatus to either foment the Arab Spring or thwart it— to bolster the tribes and undermine the Palestinians or the opposite. What all of these explanations had in common was the idea of media as a tool controlled by some power center or other for its own ends. What I want to emphasize here is that this sort of estrangement from the media is one thing when it manifests itself among the obviously marginalized and disaffected, but these were the journalists themselves.

This sort of cynicism and alienation was a reflection of the degree to which professional selfpreservation required journalists to be constantly mindful of censorship, surveillance, intimidation, blackmail, and illicit financial inducements, which in turn leads to an appreciation for the efficacy of conspiracy. Conspiracy is the basis of most nondemocratic modes of governance, where deliberation happens far from public view because the people are seen not as a source of authority but as an impediment to its exercise. Such a state of affairs also makes

${ }^{10}$ For a press account of the national soul-searching around university violence, see Sweis (2013). 
it exceedingly difficult to know who is really in charge. The key question becomes one of who (or, more precisely, what) protects the visible symbols of authority while successfully cloaking itself and thereby gaining the power to withdraw that support at will. We also lose a sense of whether, or at least which, symbols of authority are actually under attack. In contemporary Jordanian media ideologies, it is the media that increasingly fulfills this explanatory role, often helping commentators contemplate the existence of covert channels that allow for the manipulation of the ostensible sources of authority within society (the state, the monarchy, foreign powers) by shadowy networks with opaque intentions. "Media ideologies" become the ideologies par excellence for an era of liberalization and privatization. They represent a vernacular idiom that in some ways prefigures and in other ways simply extends the arguments of theorists such as Timothy Mitchell, who argues that analysts should focus on how the boundary between state and society becomes "a mechanism that generates resources of power" (1991:90)—perfect for the era of public-private partnerships (PPPs), governmentorganized nongovernmental organizations (GONGOs), and media liberalization.

Needless to say, in my interactions with the journalist (as with the others), I was deeply aware of my own positionality and, in particular, the constant joking about me being a spy, including mock denunciations, mock attempts to audition for the role of CIA asset, and moments when people suddenly became genuinely suspicious and reticent. Perhaps, much like the anthropologist Katherine Verdery (2018), I was actually the mark: the one being spied upon as Jordanians rightfully suspicious of U.S. machinations scrambled to understand what these new media technologies were doing and how the Americans could be prevented from turning those technologies against Jordan and its sovereignty. If anything, it sometimes seemed that the more people were convinced I was a spy, the more eagerly they messaged me, invited me for coffee, and helped arrange meetings with other people. Undoubtedly, the fact that I was American accentuated these dynamics, but the dynamics themselves were also necessarily an extension of organizational logics that pervaded Jordan long before I arrived in ways that, happily, made me irresistible to most of the people I needed to interview. While these modes of reasoning long predated the emergence of social media, social media fed into them, as older modes of mediation - from the barber shop and the system of tribal dispute resolution to the uniformed intelligence services and official state media-were increasingly supplanted by a globalized, privatized, and unpredictably regulated information economy. In the next section, 
I show how these perspectives came to life in spectacular fashion when a Jordanian soldier was convicted of killing four U.S. military trainers.

\section{The Abu Tayeh File}

The Abu Tayeh file, as it came to be known, was shrouded in controversy and secrecy from the beginning. The Jordanian at the center of it was a man named M'aarek Abu Tayeh, a member of the Howeitat tribe, which includes tens of thousands of tribespeople in Saudi Arabia, Egypt, and southern Jordan. What's more, he shared a name with Auda Abu Tayeh, the leader of the Arab Revolt, the British-Arab assault on the crumbling Ottoman Empire at the end of World War I that brought the Hashemites to power and cemented the political accommodation between the monarchy and the tribes. Kinsmen described M'aarek as a typical family man who had spent the better part of his adult life in the Royal Jordanian Air Force. At the time of the incident, he was on guard duty in front of the base in his hometown of Al-Jafr. There was a firefight that left Abu Tayeh injured and four U.S. military trainers dead, but accounts differ ${ }^{11}$; Abu Tayeh's supporters offered a range of rationales defending him against accusations that he had murdered the trainers in cold blood. When Abu Tayeh was convicted of their murder by a state security court that had operated largely under the radar of mainstream Jordanian news since the incident, the south of Jordan erupted in protests fueled in large part by tribal Facebook pages and other social media. The Abu Tayeh name combined with the current political accommodation among his kin, the West, and the Hashemite family seemed to open up an irresistible imaginative space for reconceptualizing relationships between kin groups, the nation, and the great powers.

M'aarek's defense in court sought to counteract the government's claims that (for reasons that purportedly had nothing to do with terrorism but that were never entirely clear) he had intentionally and without justification killed four U.S. military trainers who had been operating out of the base for some time. His public defense, mirroring the initial official account offered by the Jordanian authorities, was that the Americans had failed to identify themselves and that his response had followed the rules of engagement under which he was supposed to operate given the heightened threat of terrorism. In numerous discussions with his kin at weddings

11 Among others, Bulos (2017) and Phillips and Hubbard (2017) wrote press accounts of the incident, the subsequent trial, and the reaction to the verdict. 
and other gatherings (including interviews with some of his most prominent public defenders), there seemed to be genuine shock when he was convicted. The Howeitat had been under the impression that this would all be hushed up and that, if they cooperated with the security apparatus, their kinsman would not be punished for what were clearly the Americans' missteps. They believed that his prosecution after the initial, exculpatory claims by the Jordanian authorities had been little more than an attempt to pander to the Americans. Indeed, even after the conviction, some of the more cautious argued that the family should take a docile stance and wait for the families of the Americans to relax their pressure on the U.S. Embassy so that the king could pardon Abu Tayeh.

In the absence of coverage on most major news sites and with the majority of the protests happening in isolated, rural areas, the center of the action concerning the Abu Tayeh file seemed to be the tribal Facebook groups, which took off like wildfire in the aftermath of the verdict; the largest reached nearly 100,000 followers. What had previously been sleepy clearinghouses for the electoral slates of various sections of the tribe morphed into the aspiring voices of a tribe-indeed the aspiring voices of a nation. The content featured youths in Bedouin regalia engaged in hit-and-run acts of vandalism and sabotage across the southern desert; they were burning tires and waving guns in the streets. These images were accompanied by threats to cut the power and water supplies to the capital and begin a wider insurrectionall expressed as a defense of Jordan's sovereignty. Amid the photographs and the communiqués, a large conference was organized that drew support from thousands of tribesmen from all over the country; this gained the widespread press coverage that the hitand-run attacks in isolated and unguarded stretches of infrastructure dramatized through viral pictures and video had not.

Among the family and, increasingly, among a wide cross section of Jordanians, a more sinister account of what was going on began to spread. In a lighter version of the pro-M'aarek narrative, a group of violent, corrupt, drunk, and out-of-control mercenaries had come back after a bad night out and wantonly attacked the base. For those closer to the family and closer to the base, an even more sinister version percolated. This version focused on the covert U.S. aid to the Syrian opposition that seemed to be at the heart of the case: conflicts over the sizeable amounts of money, weapons, and training opportunities that were at stake. Here, 
M'aarek became the fall guy for war profiteers. In this version of the story, the soldiers weren't even necessarily killed by M'aarek. Many believed that the soldiers were "liquidated"12 after the fact in a cover-up, along with a number of Syrians who were purportedly buried somewhere in the desert. ${ }^{13}$ Kinsmen appealed to their intensive local knowledge of the isolated desert terrain, claiming (to me, among others) that they had stayed quiet about what was happening at the base for decades. A common refrain was, "People wouldn't have believed us anyway... But we live there. We know everything."

In a wide-ranging interview at a villa in the capital with of one of $\mathrm{M}^{\prime}$ aarek's defenders with ties to the royal court and the security services, family members were eager to name names and counsel me that U.S. intelligence assets were out of control and needed to be reined in. In a moment of anger, the patriarch became especially agitated: "Fox News understands a little and Al-Jazeera English understands a little.... [But] for nine months there has been a campaign against us. All they say is 'killed in cold blood, killed in cold blood, killed in cold blood.' It's all documented but they only publish his name, Abu Tayeh, Abu Tayeh, Abu Tayeh, cold blood, cold blood." The phrase seemed to drip off his tongue like bile. Despite my best efforts to assure everyone I spoke to that I was neither a spy nor a back channel to the United States embassy, family members pleaded their case with alacrity. At times, they seemed genuinely convinced of their kinsman's innocence and determined to find an American who would hear them out. They even told me that, in light of the hundred-year, mutually beneficial relationship between the family and the West, they had made extensive efforts to reach out the families of the dead to explain what a terrible misunderstanding this all had been. At other times, though, they complained bitterly of sky-high unemployment in the community, a lack of development, low pay in the security services, and exclusion from emerging paths to upward social mobility, implying none-too-subtly that these issues might have also factored into the case somehow.

The attempt to turn the Abu Tayeh file into a cause célèbre quickly ran into a range of problems. Members of the Abu Tayeh section of the Howeitat came to resent that a rival

\footnotetext{
12 The idea of "liquidation" (tasfiyya) is used to refer to how those inconvenient to the powers that be are clandestinely eliminated. One particularly recurrent image associated with the term involves the hapless victim being injected with a poison by a fast-moving operative who then makes his escape as his victim appears to suddenly be taken violently ill and expire.

${ }^{13}$ In fact, at least one American survived the attack and provided an eye witness account to U.S. media sources (Phillips and Hubbard 2017).
} 
faction known as the bin Jazi controlled the Facebook group with the most followers. In an ironic recapitulation of history, this was the same family that had best capitalized on the Hashemite ascendency, leaving the Abu Tayeh section of the family working government jobs in the desert while the bin Jazi moved into elite positions in the capital and became the paramount sheikhs. At the same time, the killing of a Jordanian handyman in Amman by an Israeli Embassy guard over a screwdriver (purportedly one that could have been used as a weapon) put pressure on supporters of the two cases to combine causes. Yet both eyed the other with suspicion, not wanting to dilute a family issue with a broader national issue. Members of the Howeitat were keen to distinguish their "genuine" case from the "true crime" that had occurred in Amman, and to remind me that they weren't like those "city folk." As I was often told, "There are only ten real Jordanians in Amman."

Ultimately, combining forces proved impossible. This draws to the fore questions not just of how tribes see one another but also of how they may be seen. One of M'aarek's more tireless defenders reasoned, 'If I put [out] 'the great Satan' and 'Death to America,' they will all stand with us, all of Amman... Al-Manar (Hezbollah's TV station) Al-Mayadeen (a Lebanese station), RT (formerly Russia Today), leftist parties, rightist parties, the birak (social movements).... One word issued from the Bedouin and they will all stand with us." Yet in the end, he couldn't do it.

The final blow to the Abu Tayeh cause seemed to come when, after weeks of protests and angry demands for surveillance footage of the clash to be released, the Jordanian government released a video that was widely disseminated via online media. It clearly showed a group of soldiers arriving at a base_-all meticulously following proper procedures-being shot at for about four minutes while trying to deescalate the situation as the Jordanian soldiers at the base looked on. A lot of Abu Tayeh's kinsmen found the video comical at first, still finding it implausible that one man could kill four soldiers in front of a military base and live-and joking that "he's not Rambo." They dismissed the video, arguing that the movements of the soldiers looked stilted, like bad acting. While Abu Tayeh's kinsmen were adamant that the video was fake, most interest in the case-including the protests—-died out soon after. At the time of writing, the family is still waiting for the king (or perhaps the Trump administration) to come to their aid. Most tellingly, the case never seemed to be able to produce a leader with 
a name and face. Instead, it was as if Abu Tayeh himself was the only person suitably positioned to lead the revolt_-from beyond the grave. Others shrank from the task, either afraid to risk their villas and titles or not of sufficient account to matter.

\section{Conclusion}

Taken in concert with actual events like the Abu Tayeh affair, the claims of these differently situated social actors (sheikhs, policemen, and journalists) temper one another's more extreme assertions while valorizing their basic-if somewhat opposed-perspectives on the changing role of media in the construction of authority in contemporary Jordan. On the one hand, the fears of the policeman and the sheikh that Jordan is rapidly spinning out of control seem unfounded: tribal conflict still seems to dissipate tensions as much as it organizes them-and each year, the Arab Spring fades further into the background and seems more and more like a nonevent. The same goes for the more extreme fears of the journalist that he is but a $\operatorname{cog}$ in a system of surveillance that he cannot begin to fathom, working to advance interests that might be completely counter to his own. What I found was not a well-oiled apparatus of social control with lavish funding and dedicated cadres of experts working night and day while weaving together intelligence gathering, law enforcement, and propaganda, but rather a decentralized, alienated, and highly ambivalent collection of relatively isolated individuals. These were people inclined to eye everyone around them as both foe and potential allyincluding the foreign ethnographer-interloper. Yet while the reciprocal mistrust and paranoia manifest across the social field might be perceptive and well founded, the key features of the most prevalent media ideologies that I encountered also helped produce what one might (depending on one's perspective) call either stability or paralysis, effectively maintaining the status quo. Here, I would argue that it is best to focus less on particular collections of shadowy interests and more on the media ideologies that promote the belief in such shadowy networks of interests, seeking to understand what such ideologies do to a country's politics.

Censorship is, of course, inherently difficult to study, but Jordan's quasi-regulated media does not seem to suppress social conflict-nor does it seem to focalize it on the visible centers of power. To the contrary, it seems to refract conflict in a range of unpredictable directions, forcing everyone from local notables to journalists to members of the security apparatus to eye one another warily and be prepared to switch allegiances should the political winds change. 
The degree to which journalists in particular now play into the publicization of threats to public order in real time marks a notable departure from decades of accepted practice. Yet it is unclear whether the increasingly widespread dissemination of news about all manner of such threats actually substantively challenges state authority. This dynamic is consonant with findings elsewhere. For instance, in a recent, large-sample, quantitative study of Chinese-state thought management, King, Pan, and Roberts have found that the statements most likely to be censored on the Chinese Internet are not criticisms of the government but collective expression (2013), and that large numbers of fabricated posts seem aimed at distraction as opposed to argument (2017). While Jordan is far more open, it is easy to discern similar logics at play behind the kingdom's apparent red lines. The media ideologies I have tracked in this paper all seem to accentuate the difficulty of ever really knowing where genuine political solidarity might emerge if not from the particularity of kinship, patronage, and neighborhood defense.

The emergent socially networked tribal publics that I have documented here are very much at odds with both Jurgen Habermas' rational-deliberative "public sphere" (1989) and Michael Warner's “counterpublics," which, despite challenging “modernity's social hierarchy of faculties," "do so by projecting a space of discursive circulation among strangers as a social entity, and in doing so fashion their own subjectivities around the requirements of public circulation and stranger sociability" (Warner 2002:87). In contrast, the attraction of tribal publics seems to be precisely their inability to conform to the requirements of true public circulation and stranger sociability, forcing a more irrevocable sort of allegiance onto social actors. It seems as if the very uprootedness and promiscuity of new media has come to encourage a valorization among even the most marginal to the status quo in Jordan of what Geertz (1963) called the "primordial ties" of kinship, ethnicity, and "blood"—primordial not because they are in fact primordial (because they are not) but because they seem that way. If anywhere, it is here that the nature of authority seems to be subtly morphing. Take the Abu Tayeh file: there is nothing timeless about it. Its historical depth, even insofar as participants were reaching back to the Great Arab Revolt, is but 100 years old: old enough ago to feel both totalizing and venerable, but recent enough to feel both intimate and immediate. At a moment when people feel increasingly connected to distant sources of power, such a conflict is resolutely local, grounded in incontrovertible daily realities of neighborhood, mutual defense, 
and political patronage. These media ideologies, with their emphasis on media as a tool for affecting power at a distance, may therefore somewhat counterintuitively bolster preexisting structures of authority by pushing people to seek a grounding in the visible, the tangible, and the ready-to-hand-even if a few old men are humiliated in the process. 


\section{References}

Amos, Deborah. 2013. "In a rough neighborhood, Jordan clings to its stability." National Public Radio. Online document.

https://www.npr.org/sections/parallels/2013/07/01/196656296/stability-ordemocracy-in-jordan-its-a-fragile-balance.Accessed May 4, 2018.

Armbrust, Walter. 1996. Mass Culture and Modernism in Egypt. Cambridge, UK: Cambridge University Press.

Baker, Aryn. 2011. "In Jordan, the king decides it's the right time to clean house." Time. Online document.

http://content.time.com/time/specials/packages/article/0,28804,2045328 204533320 45565,00.html Accessed May 4, 2018.

Brady, Anne-Marie. 2008. Marketing Dictatorship: Propaganda and Thought Work in Contemporary China. Plymouth, UK: Rowen and Littlefield.

Brady, Anne-Marie, ed. 2012. China's Thought Management. London: Routledge.

Bulos, Nabih. 2016. "Jordanian journalist shot to death on courthouse steps after posting controversial cartoon to Facebook." Los Angeles Times. Online document. http://www.latimes.com/world/middleeast/la-fg-jordan-journalist-killed-cartoon20160925-snap-story.html Accessed April 3, 2017.

Bulos, Nabih. 2017. "Jordanian soldier sentenced to life in prison in killing of three U.S. military trainers." Los Angeles Times. Online document.

http://www.latimes.com/world/middleeast/la-fg-jordan-us-soldiers-killed-20170717story.html. Accessed May 4, 2018.

Calhoun, Craig. 1992. Habermas and the Public Sphere. Cambridge, MA: MIT Press.

Castillo, Michelle. 2018. "Mark Zuckerberg: Facebook is a technology company, not media company." CNBC. Online document. https://www.cnbc.com/2018/04/11/markzuckerberg-facebook-is-a-technology-company-not-media-company.html. Accessed March 29, 2019.

Cunningham, Robert, and Yasin Sarayrah. 1993. Wasta: The Hidden Force in Middle Eastern Society. London: Praeger.

Dewey, John. 1927. The Public and Its Problems. New York: Henry Holt and Company.

Dresch, Paul. 2000. "Wilderness of mirrors: Truth and vulnerability in Middle Eastern fieldwork." Anthropologists in a Wider World: Essays in Field Research, Paul Dresch, Wendy James, and David Parkin, eds. New York: Berghahn Books.

Freedom House. 2017. "Freedom on the Net 2017: Jordan.” Online document. https://freedomhouse.org/sites/default/files/FOTN\%202017_Jordan.pdf. Accessed March 29, 2019.

Gaffney, Patrick. 1998. The Prophet's Pulpit: Islamic Preaching in Contemporary Egypt. Berkeley: University of California Press.

Geertz, Clifford. 1963. "The integrative revolution: Primordial sentiments and civil politics in the new states" in Clifford Geertz, ed. Old Societies and New States: The Quest for Modernity in Asia and Africa. New York: Free Press. 107-113.

Gershon, Ilana. 2010. The Breakup 2.0: Disconnecting over New Media. Ithaca: Cornell University Press.

Glennon, Michael. 2014. National Security and Double Government. Oxford: Oxford University Press. 
Hirschkind, Charles. 2006. The Ethical Soundscape: Cassette Sermons and Islamic Counterpublics. New York: Columbia University Press.

Hughes, Geoffrey. 2018. "Cutting the face: Kinship, state, and social media conflict in networked Jordan.” Journal of Legal Anthropology 2(1):49-71.

Jordan Times. 2018. "Facebook most popular social media site in Jordan—report." Jordan Times. Online document. http://www.jordantimes.com/news/local/facebook-mostpopular-social-media-site-jordan-\%E2\%80\%94-report. Accessed March 29, 2019.

Lynch, Daniel. 1999. After the Propaganda State: Media, Politics, and "Thought Management" in Reformed China. Stanford: Stanford University Press.

Habermas, Jurgen. 1989. Structural Transformation of the Public Sphere. Cambridge, MA: MIT Press.

He, Zhou. 2000. "Working with a dying ideology: Dissonance and its reduction in Chinese journalism.” Journalism Studies 1(4):599-616.

Kenez, Peter. 1985. The Birth of the Propaganda State: Soviet Methods of Mass Mobilization, 19171929. Cambridge, UK: Cambridge University Press.

King, Gary, Jennifer Pan, and Margaret E. Roberts. 2013. "How censorship in China allows government criticism but silences collective expression." American Political Science Review 111(3):484-501.

King, Gary, Jennifer Pan, and Margaret E. Roberts. 2017. "How the Chinese government fabricates social media posts for strategic distraction, not engaged argument." American Political Science Review 107(2):326-343.

Layne, Linda. 1989. "The dialogics of tribal self-representation in Jordan." American Ethnologist 16(1):24-39.

Layne, Linda. 1994. Home and Homeland: The Dialogics of Tribal and National Identities in Jordan. Princeton: Princeton University Press.

Lippmann, Walter. 1922 [reissued in 1997]. Public Opinion. New York: Free Press.

Lynch, Marc. 1999. State Interests and Public Spheres: The International Politics of Jordan's Identity. New York: Columbia University Press.

Lynch, Marc. 2005. Voices of the New Arab Public: Iraq, Aljazeera, and Middle East Politics Today. New York: Columbia University Press.

Massad, Joseph. 2001. Colonial Effects: The Making of National Identity in Jordan. New York: Columbia University Press.

Miles, Hugh. 2005. Al-Jazeera: The Inside Story of the Arab News Channel That Is Challenging the West. New York: Grove Press.

Mitchell, Timothy. 1991. "The limits of the state: Beyond statist approaches and their critics." American Political Science Review 85(1):77-96.

Philips, Dave, and Ben Hubbard. 2017. "Soldier who survived shootout in Jordan tells his story." New York Times. Online document.

https://www.nytimes.com/2017/07/25/world/middleeast/special-forces-jordanshootout-survivor.html. Accessed May 4, 2018.

Price, Monroe, Andrei Richter, and Peter Yu. 2002. Russian Media Law and Policy in the Yeltsin Decade: Essays and Documents. The Hague: Kluwer Law.

Shryock, Andrew. 1996. "Tribes and the print trade: Notes from the margins of literate culture in Jordan. American Anthropologist 98(1):26-40. 
Shryock, Andrew. 2000. "Dynastic modernism and its contradictions: Testing the limits of pluralism, tribalism, and King Hussein's example in Hashemite Jordan.” Arab Studies Quarterly 22(3):57-79.

Skillen, Daphne. 2016. Freedom of Speech in Russia: Politics and Media from Gorbachev to Putin. London: Routledge.

Siegel, James. 1998. A New Criminal Type in Jakarta: Counter-Revolution Today. Durham: Duke University Press.

Sooyler, Mehtap. 2015. The Turkish Deep State: State Consolidation, Civil-Military Relations and Democracy. London: Routledge.

Sparks, Colin. 2008. "Media systems in transition: Poland, Russia, China." Chinese Journal of Communication 1(1):7-24.

Starrett, Gregory. 1995. Putting Islam to Work: Education, Politics, and Religious Tranformation in Egypt. Berkeley: University of California Press.

Sweis, Rana. 2013. "Tribal clashes at universities add to tensions in Jordan." New York Times. Online document. http://www.nytimes.com/2013/04/25/world/middleeast/tribalclashes-at-universities-add-to-tensions-in-jordan.html. Accessed March 16, 2018.

Verdery, Katherine. 2018. My Life as a Spy: Investigations in a Secret Police File. Durham: Duke University Press.

Warner, Michael. 2002. "Publics and counterpublics.” Public Culture 14(1):49-90.

Williams, Kristian. 2011. "The other side of the COIN: Counterinsurgency and community policing." Interface: A Journal for and About Social Movements 3(1):81-117.

Zhao, Yuezhi. 1998. Media, Market, and Democracy in China: Between the Party Line and the Bottom Line. Champaign: University of Illinois Press.

Zhu, Ying. 2012. Two Billion Eyes: The Story of China Central Television. New York: The New Press. 